\title{
Economic assessment of limited land resources in the mountainous territories
}

\author{
Zaur Ivanov ${ }^{1, *}$, Alim Gurtuev ${ }^{1}$, and Magamed Israilov² \\ ${ }^{1}$ Institute for Computer Science and Problems of Regional Management, Nalchik, Russia \\ ${ }^{2}$ Chechen State University, Sheripova Street, 32, Groznyi, 364093,Russia
}

\begin{abstract}
The purpose of the study is to improve the method of economic assessment of limited land resources in the mountainous territories of the North Caucasus Federal district. The article analyzes specific shortcomings of the methodology currently used in Russia, which does not have a sufficiently objective scientific basis. Our approach is based on the synthesis of modern achievements of agro-economic science. Attempts to systematize the economic assessment of land in the agricultural sector of the Russian Federation depending on the land quality did not lead to positive results. This is first aspect of the problem we are studying. The second aspect is that the problem is not developed from the economic point of view. A positive differential rent is automatically included in the market value of agricultural products. The third aspect is the formation of tax and rental rates for agricultural land in direct correlation with the cadastral value. As a result, there is a research problem of objective assessment of limited agricultural land in agriculture. The method of economic evaluation of agricultural lands of the state Committee for land use of the Russian Federation has been improved.
\end{abstract}

\section{Introduction}

Over the past 30 years, disputes over land use reform and the definition of title to agricultural land in the republics of the North Caucasus Federal District have not abated.

When conducting land reform, it is necessary to proceed from two main issues:

1. Private or public property?

2. What categories of citizens apply for a land share?

Based on local conditions, it is necessary to conclude which form of land relations is most acceptable in specific conditions. In the conditions of some regions, the choice can be made in favor of a regulated purchase and sale, while others - land lease.[1,2] Many regions of Russia on this issue have decided in favor of transferring agricultural land to private ownership through special privatization mechanisms.

To carry out effective land reform, it is necessary for the leaderships of the republics of the North-Caucasian Federal District to show political will and determine priorities in goals and objectives. The authorities must determine, during land reform, from the mass of

\footnotetext{
*Corresponding author: zaurivanov@mail.ru
} 
economic, social, environmental and political challenges that are more important and necessary for the peoples of the republics:

- increase in gross regional product;

- reduction in unemployment;

- reduction of conflict situations in land use of the republic;

- increase in the production of organic food;

- implementation of the import substitution program of sanctioned goods;

- maximization of budget revenues;

- development of rural municipalities in mountainous areas.

To determine the opinion of society in the republics in the areas of land reform, it is necessary to conduct a national referendum or conduct a public opinion poll.[3] These events will reveal the mood of people and their attitude to the reform of land relations according to the "technology of social compromise".

Also, the problem consists in an adequate understanding of the new realities of modernity in the agrarian economy by the public and in a change of title to agricultural land. In the mountainous territories of the North-Caucasian Federal District, market mechanisms in the field of land use remain undeveloped; there are no incentives for the efficient use of land and attraction of investments. The issues of maintenance, reproduction and growth of biological fertility of agricultural land are aggravated.[4, 5] Of particular social tension are the issues of providing land to the population (certain categories) for housing, for agricultural production for rent and for various other purposes.

\section{Materials and methods}

The economic assessment of limited arable land in the agricultural sector reflects their quantitative (productive) ability as the main means of production through a system of inkind (non-value, ball-ha), conditional (ratios) and cost (money, rubles) indicators. Land resources, as a necessary means of production in the agricultural sector, are characterized by different fertility and productive capabilities. Even similar sites in terms of agrobiological indicators can have different production values, depending on economic, geographical and landscape ecological indicators.[6]

Economic valuation of land is required when comparing agricultural fields and forming a land market in the agricultural sector. It is aimed at creating conditions for improving environmental protection and efficient land use, improving the economic mechanism for the distribution and redistribution of limited agricultural resources. Back in the 90s, the leadership of the Russian Federation made an attempt to gain the support of the population through land reform. As a result, household plots were transferred to private ownership free of charge, and collective and state farms to collectively shared enterprises. The reorganization of collective farms and state farms was carried out only on paper without real reforms.[7-9] The peasants were deprived of any incentive to work on collective farms. Soon the impossibility of further functioning of collective farms became apparent. Over the years, the entire process of land privatization in the republics of the North Caucasus was limited only to this first wave of reforms - the distribution of land in the form of many small plots, which was also important in a crisis situation. Another part of the state land was transferred in the form of long-term leases. But, it turned out that tenants were mainly people who had good connections with some members of the federal and regional authorities, almost completely stopped in 2012 .

The law did not guarantee the tenant the opportunity to acquire the leased land as a property, so the temporary owners of the plots, as a rule, did not try to maintain the quality of the land, but, on the contrary, tried to squeeze the maximum out of it every year by investing a minimum. Therefore, neighboring areas may have different quality 
characteristics.[10] Now there is a process of redistribution of land resources using auction mechanisms. In the framework of one article, it is impossible to highlight all the problems of land relations and give options for solving them. We indicate the land use problems typical for the mountainous territories of the North Caucasus:

1. The lack of a single automated system of accounting and use of land resources.

It will ensure access to information about land plots, copyright holders, significantly reduce bureaucratic procedures for registration of rights and corruption factors.

2. It is impossible to enter the land into effective economic circulation due to the fact that only a small part of the land is registered on the cadastral register.

In the republics of the North Caucasus Federal District, according to local authorities, only $61 \%$ of agricultural land is registered in the cadastre. In Russian legislation there is no obligation for the owner to form a land plot and put it on cadastral registration, while budget financing for these works has never been foreseen. Land plots that are not registered with the cadastre are not taxed, and rents are not included in the budget, i.e. not involved in economic turnover. The lack of cadastral registration of land is one of the main reasons for their involvement in the agricultural sector of the region's economy.

3. The lack of updated cartographic material of the boundaries of municipalities with the preparation of map plans of land management objects. Subsequent entry of information into the state real estate cadastre.

Agricultural land valuation results may have a value (monetary) and non-value (natural) expression. The value expression is measured in national currency per unit area (1 ha), based on the data of its value, location, availability of irrigation and other factors of production. Land use income, rent, land tax and land rent are indicators of the economic value of land. A natural assessment includes indicators of biological fertility, topography, climatic features and the level of land productivity with the achieved level of scientific and technological progress in the agricultural sector. A non-valuation of the plots is necessary when choosing crops and the technology of their cultivation, optimizing land circulation.[11]

The question arises about the reason for the approval of the cadastral value, in general, for farmland without a breakdown into arable land, gardens and fodder land, of a significant difference in the value of individual plots located both in the neighborhood and at a short distance from each other. All this significantly reduces the quality and level of work done on the economic valuation of agricultural land.

We consider it appropriate to review the current methodology for determining the cadastral value of agricultural land during the next update of the state cadastral valuation of agricultural land, which, as a result, will affect the amount of rent. In the USSR, every 5 years, agricultural land was assessed for the biological, agrochemical and economic fertility of the plots, and based on these analyzes, agricultural (agronomic) maps were used - land use maps, which showed changes in soil fertility, thickness of the humus layer and the level of wind and rain erosion. It is recommended that such work be resumed on an ongoing state basis using advanced information technologies. It is proposed to create an automated cartographic environmental-agro-economic information and consulting system of land use in the regions of the North-Caucasian Federal District - an automated system for maintaining the state land cadastre. Without the delimitation and assessment of land it is impossible to collect property taxes, which form the basis of local budgets, while local authorities practically do not deal with this problem. [12, 13]

To achieve justice in land reform, it is necessary to study the agrotechnical characteristics of farmland and develop a system of coefficients that can be used to evaluate and compare the economic and biological fertility of any plot with a reference (transfer all agricultural land to service). As a reference, you can take the most common soil type in a given municipality. [14] 
There are 37 types of soils in the North Caucasus Federal District that have different economic values depending on the depth of the humus layer. For example, 1 ha of irrigated chernozem with a humus layer depth of $1 \mathrm{~m}$ by economic and biological fertility is equal to 2 ha of meadow soils, with a humus depth of $0.5-0.6 \mathrm{~m}$ or 10 ha of pasture land.

Attempts to systematize the economic valuation of land in the agro-industrial complex depending on the qualitative characteristics of the site did not lead to positive results.[15] This is one aspect of the problem we are investigating.

The second aspect is that the problem is not developed from the point of view of basic economic science. Positive differential rent is automatically included in the cost of sales of agricultural products.

The third aspect is the formation of a tax on agricultural land in direct correlation with the cadastral value. As a result of the problems noted, the research task of an objective assessment of limited agricultural land in the agricultural sector arises.

\section{Results and conclusion}

We made an attempt to refine the methodology of the State Committee of the Russian Federation, which does not meet the modern realities of economic science. We show the main provisions of the methodology of economic valuation of farmland:

$$
R_{i}=n_{i} l_{i} / t
$$

where, $R_{i}$ - annuity value for 1 year on the i-th land plot, rub.; field;

$n_{i}$ is the share of differential land rent in the gross (commodity) production of the $\mathrm{i}$-th

$l_{i}$ - total revenue from the sale of gross output from the i-th plot at average prices for the year in the region for the evaluation period, rubles;

$t$ is the duration of the time lag for estimating the $\mathrm{i}$-th field, years.

In expression (1), the weight of differential land rent in the gross production of the $i$-th plot is determined as follows:

$$
n i=1-c i / l i
$$

where, $c_{i}$ is the total cost of gross (or salable) products from the i-th plot for the analyzed period, rubles.

The proceeds from the sale of products in average regional prices for the i-th field for the analyzed period is determined by the following formula:

$$
l_{i}=Y_{i} Y_{t} p_{k p} \times v_{i j t}
$$

where, $p_{k p}$ - the average selling prices for the subject of the North-Caucasian Federal District of the $\mathrm{j}$-th agricultural product for the period $\mathrm{t}(\mathrm{j}=1,2, \ldots, \mathrm{N}$ is the number of the type of commercial products), rubles / centner;

$v_{i j t}$, - the number of products on the $\mathrm{i}$-th plot of the $\mathrm{j}$-th product for one growing season, t.

In turn,

$$
p_{\mathrm{kp}}=Y_{i} Y_{t} p_{j i t} \times v_{i j t} / Y_{i} Y_{t} v_{i j t}
$$

where, $p_{j i t}$ is the selling price of the $\mathrm{j}$-th product by the $\mathrm{i}$-th field in the $\mathrm{t}$-th year, rubles / c.

In (2), the total cost of gross output from the i-th land plot for the base period is found by the formula: 


$$
c_{i}=Q Y_{j} Y_{i} s_{i j t} \times v_{i j t},
$$

where, Q is the payback ratio of production costs in non-rental sectors of the regional national economy;

$s_{i j t}$ - the cost of growing the $\mathrm{j}$-th type of product in the $\mathrm{t}$-th year on the $\mathrm{i}$-th land plot, rub / c. As a result of the transformations we get:

$$
R_{i}=\left[1-Q\left(Y_{j} Y_{i} s_{i j t} \times v_{i j t}\right) / l_{i}\right] l_{i} / t .
$$

And if we divide the obtained value by the production area, then we will get the result per 1 ha.

Obviously, in (9), when $l_{i}$ exceeds $c_{\mathrm{i}}$, the rent will be more than zero $\left(R_{i}^{+}\right)$, if $c_{\mathrm{i}}$ exceeds $l_{i}$, the rent will be less than zero $\left(R_{i}^{-}\right)$.

You calculate the positive rent for the $R^{+}$region by the formula:

$$
R^{+}=Y_{i} R_{i}^{+}
$$

Negative $R^{-}$- by the formula:

$$
R^{-}=Y_{i} R_{i}^{-}
$$

If we talk about the price of the i-th land plot $\mathrm{Z}$, then it is found by the well-known formula:

$$
Z_{i}=R_{i}^{+} / I
$$

Where, I - interest rate of the loan.

Since the lending rate during the crisis period is unstable, agricultural economists suggest using a different formula when calculating the price of land:

$$
Z_{i}=R_{i}^{+} \times 33,
$$

Where, 33 - the term of capitalization, years.

\section{Conclusion}

In the process of determining the economic valuation of land, it is advisable to carry out the following land management works, including:

- inventory of federal, republican and municipal land plots;

-conducting eco- and agro-soil, geobotanical, agrochemical, topographic, geodetic and other surveys;

- classification of all agricultural land shares according to economic fertility and agricultural categories.

The agricultural policy of the republics of the North Caucasus Federal District, in our opinion, should provide for the division of plots into agricultural zones, with the establishment of their permitted and optimal use - Green plans. The Green Plans should define agricultural zones (districts), including a recommended list of promising areas of agricultural production, a set of measures to protect fertility within these zones (regions), placement of agricultural processing clusters, territories that are unsuitable and unsuitable for agricultural production

The revised methodology for economic assessment takes into account the economic and natural productivity of agricultural land, which is necessary to achieve socially fair results of land reform in the republics of the North-Caucasian Federal District. In conclusion, it 
should be noted that for the successful solution of very acute problems in land relations, the coordinated work of agricultural producers and authorities is necessary: the Ministry of Land and Property Relations, the Ministry of Agriculture; territorial federal institutions: Roskadastra, Rosreestra, Federal Property Management Agency; local authorities (urban districts, regions, settlements); public organizations and national movements.

The research was supported by the Russian Foundation of Basic Research, grant No. 20-010-00269A "A mechanism for mountainous regions development management on the basis of a the new architecture of local socio-economic systems" and grant No. 19-010-00577A "Problems of counteracting agency opportunism in multi-level systems with information asymmetry".

\section{References}

1. T. Besley, R. Burgess, QJE 115 (2), 389-430 (2000) doi: https://www.jstor.org/stable/2586998

2. B. Cousins, I. Scoones, Journal of Peasant Studies 37 (1), 31-66 (2010) doi: 10.1080/03066150903498739

3. D.Benjamin, L.Brandt, J.Giles, Economic Journal 121 (557), 1281-1309 (2011) doi: $10.1111 / \mathrm{j} .1468-0297.2011 .02452 . x$

4. H. Friedmann, The Journal of Peasant Studies 46 (5), 1096-1105 (2019) doi: 10.1080/03066150.2019.1608684

5. J. Clemens, AER 103 (3), 523-527 (2013) doi: 10.1257/aer.103.3.523

6. E. Aryeetey, C. Udry, AER 100 (2), 130-134 (2010) doi: 10.1257/aer.100.2.130

7. A. Gurtuev, E. Derkach, Z. Ivanov, Izvestiya, KBNC RAN 4 (78), 59-65 (2017)

8. T. Straka, S. Bullard, Journal of the ASFMRA, 190696 (2006) doi: 10.22004/ag.econ.190696

9. J. Kirsten, C. Machethe, University of Pretoria Working Papers, 241848 (2005) doi: 10.22004/ag.econ.241848

10. Y. Qi, Y. Zhao, N. Hu, et al., Asian Agricultural Research 04 (05), 139480 (2012) doi: 10.22004/ag.econ.139480

11. P. Bardhan, M. Dilip, AER 100 (4), 1572-1600 (2010) doi: 10.1257/aer.100.4.1572

12. K. Emerick, A. de Janvry, E. Sadoulet, M. H. Dar, AER 106 (6), 1537-1561 (2016) doi: 10.1257/aer.20150474

13. B. Daley, B. Green, AER 110 (2), 428-474 (2020) doi: 10.1257/aer.20181316

14. R. Jayaraman, D. Ray, F. de Véricourt, AER 106 (2), 316-58 (2016) doi: 10.1257/aer.20141122

15. K. Burchardi, S. Gulesci, B. Lerva, M. Sulaiman, QJE 134 (1), 281-347 (2019) doi: 10.1093/qje/qjy023 